\title{
Buryat Ethnic Mentality and National Broadcasting
}

\author{
E.D. Dagbaev ${ }^{1}$, N.Zh. Dagbaeva ${ }^{1, a}$, P.P. Dashinimayeva ${ }^{1}$, S.K Zandeeva ${ }^{1}$ \\ ${ }^{1}$ Buryat State University, 67000, Smolina str., 24-a, Ulan-Ude, Russia
}

\begin{abstract}
The article focuses on ways the national (in a regional aspect) broadcasting impacts ethnic mind formation and its further development, the latter issues being under a main focus of Buryat State University scholars as well. They set an objective to investigate the issue from different angles, for this reason gathering within scientific projects into scholars'groups took place. In this case the group of educators, philologists and sociologists have focused on media which construct ethnic mind via interiorizing and cultivating ethnic-related ideas and images for five years. Providing a general outlook of the world, National Broadcasting (NB) is a proper institutional mechanism that helps a person identify himself / herself among different ethnic groups. Ethnic identity and self-consciousness are manifested in various social and intercultural communications. This allows a person to become aware of the peculiarities of his / her and others' ethnic communities. The outcomes of a sociological research held by the authors verify the significance of both the posed problems and the TV role. One may find theoretical and empirical data in Zandeeva, S.K. (2012), Dagbaeva, N.Zh.(2012), Dagbaev (2014), Dashinimaeva, P.P., et al (2015). Generally, national programs do contribute to integrating people of the same ethnicity into a common community, to shaping such moral qualities as humanity, love to motherland, respect for the elders and other ethnic nationalities. All these characteristics form proper rules of living in a tolerant community. At the same time, they contribute to strengthening of the feeling of ethnic unity. Beyond any doubt, NB needs a relevant assessment and interest to promote and advance its function in a modern society. On the one hand, telecommunications markets liberalize. On the other hand, broadcasting technologies have developed to a highest extent, leading to the increase of international competition [14]. Anyway, both directions force the national broadcasting to review their trends.
\end{abstract}

\section{Introduction}

National television plays an important role in an ethnic identity development. However, this role is hardly made aware of, for television is considered to be an entertainment tool. Here we put the question What might be regarded as National Broadcasting (NB)? By this term we mean regional TV companies of national republics. Let us note that there are 89 branches of the Federal State Unitary enterprise (FSUE), the All-Russian State Television and Radio Broadcasting company (ARTRBC) in Russian regions. And only 30 channels belong to national TV and radio broadcasting. In Siberia 6 regions have NB: Republics of Altai, Buryatia, Tuva, Khakassia, Chita region and Novosibirsk region. The television in the Buryat language broadcasts in the Republic of Buryatia and Chita region, the latter's office, «State Television and Radio company "Chita", being in the settlement "Aginskoye". The extent of national programs production on public TV channels ranges from 3 to 4 hours a day.
So, the reason for having NB is defined by the fact that Russian humanitarian scientific knowledge traditions differ much from the ones accepted in western countries. We will empirically figure out a role which NB plays in ethnic identity formation.

\section{Materials and methods}

Some researchers believe that NB implies so called "ethnic mass media". Thus, V. K. Malkova refers to them newspapers, magazines, TV and radio broadcasting addressed to an ethnic group, related ethnic groups and sometimes to fellow countrymen - people coming from the same region. Here she considers the terms "ethnicoriented mass media" and "the press and television of ethnic groups" to be more appropriate, although the terms "ethnic media", "ethnic press", "ethnic television" and etc. might be used as well [11].

In term identification N. Kondakova goes significantly further. According to her definition, all media channels functioning in Russia in all national

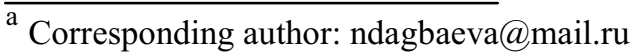


languages, except Russian, can be called "ethnic" or "national" [9].

$\mathrm{K}$. Aliev refers all channels, which are on in national republics all over Russia, to "ethnonational" [1].

However, in our case the use of "ethno" is not quite acceptable because it does not take into consideration peculiarities of TV broadcasting in our country. Indeed, on the one hand, there are ethnic mass media, that is the media of expat communities and ethnic groups broadcasted in different languages, including Russian. Ethnic mass media may equally include numerous religious periodicals, their readers dominantly belonging to the same ethnicity. On the other hand, such allnational TV companies as "The First Channel" or "Russia" are called all-Russian or federal channels but not national ones.

Therefore, labeling regional (or republican) television as "national" has been a tradition so far. To add, one relate to regional /national media not only channels that broadcast in ethnic language, but also radio and press. To exemplify, L. D. Dryakhlova calls the TV broadcasting of the republic of Mordovia as national, which is in Russian, Moksha and Erzya languages [7].

Sticking to the researchers' opinion, we are inclined to name the like $\mathrm{TV}$, broadcasting in the republics of Russia, as "national", because they piloted alongside with the foundation of Russian TV industry in general. Then, for many decades, this TV contributed to consolidation of Russian ethnic groups via involving them into the system of inter-ethnic communications, to preservation and further development of the national culture and the language.

Thus, NB is regional mass media, television which broadcasts in ethnic languages of different folks of the Russian regions. The main peculiarity of national TV broadcasting is bilingualism, which is of substantial meaning in TV media. We refer affiliated branches of FSUE ARTRBC and other regional commercial TV channels, which work in the format of NB, to them. Russian-non-Russian bilingualism on TV channels is one of the established factors to develop TV broadcasting for indigenous people all over Russia, bilingualism being a relevant guideline to include and to show all possible relations.

The objective set before the researchers defined a sampling principle - to enroll Buryat respondents. Then parent population set the parameters and quota samples. Further on, a questionnaire was worked out for a target TV audience of the Republic and the number of people participating in the study reached 450. They are bilinguals speaking Russian and Buryat, from 15 to 70 years of age, prospective and real TV viewers from Tunka, Oka, Ivolga and Zaigraevo districts, and the city of Ulan-Ude.

The questionnaire includes the following units: TV audience's «social and demographic characteristics» to figure out occupation, a marital and social group status, age, an education level, a place of residence; «TV program viewing and assessment frequency» to reveal time spent on watching, a channel and a genre preferencies, national program topics and a current state of affairs; «NB impact on interethnic relations» to consider relations between Buryats and other peoples, which reveals availability or lack of conflicts, a tolerance grade in ethnic interactions, an ethnic identity type, neighborhood, business, friend and family contact feasibility etc.

\section{Results and discussion}

In Buryatia there are two commercial TV companies except RTRBC «Buryatia». They are "Arig Us" and "TV com". Among cable TV broadcasting channels there is "Mir Buryatia".

Analyzing the extent of FSUE ARSTRC affiliated branches, we consider that the broadcasting network is made universal for all regional TV and radio channels. However, in spite of a critical approach to having an insufficient time portion, the volume of STRBC "Buryatia" TV broadcast cannot be regarded as minor. According to the 2012 statistics, "Buryatia" TV broadcast extent is as follows:

Table 1. STRBC "Buryatia” TV Broadcasting Extent in 2012

\begin{tabular}{|l|c|c|}
\hline \multicolumn{1}{|c|}{ Products in Items } & $\begin{array}{c}\text { Plan (per } \\
\text { hour) }\end{array}$ & $\begin{array}{c}\text { De Facto } \\
\text { (hour/minute) }\end{array}$ \\
\hline Total: & 710 & 695,7 \\
\hline $\begin{array}{l}\text { News programs, news and } \\
\text { analytical newscast, including } \\
\text { those in the Buryat language }\end{array}$ & 520 & 515,5 \\
\hline $\begin{array}{l}\text { Cultural and public awareness } \\
\text { programs including those in } \\
\text { the Buryat and Evenki } \\
\text { language }\end{array}$ & 105 & 103,5 \\
\hline $\begin{array}{l}\text { Art and journalistic programs } \\
\text { including those in the Buryat } \\
\text { language }\end{array}$ & 32 & 93 \\
\hline Advertisement & 25 & 72,7 \\
\hline $\begin{array}{l}\text { The overall volume of } \\
\text { national TV broadcasting } \\
\text { (hour/minute) \% }\end{array}$ & 205 & 28 \\
\hline & $29 \%$ & $28,6 \%$ \\
\hline
\end{tabular}

According to these data we can see that the biggest part belongs to news broadcasting ( 520 hours). At the same time art broadcasting, which was always dominant and traditionally strong in republics, retains its positions. The factual volume consisted of 685,7 hours, NB being broadcasting during 199,2 hours, i.e. $28,6 \%$ of the total.

$96 \%$ of the respondents turned out to be prospective viewers having TV at home, about $73 \%$ of them watch satellite and cable broadcasting. $4 \%$, predominantly students, do not have a TV-set. All of the viewers, except for $6 \%$, have a weekly time-sheet at hand. $78,35 \%$ of the testees regularly watch TV, $16,06 \%$ do it more rarely. The one who preferably switches a channel and selects a program for co-watching is a man. In addition, in $75 \%$ of cases it is not an individual process, but co-watching.

The results show that TV watching takes more time than reading or doing household chores compared to all kinds of leisure. On weekdays research subjects (32\%) spend 2 or 3 hours daily on weekends watch-time. In case of $47 \%$ of testees this index rises up to 3 or 4 hours 
(see diagram 1). The ones who sit in front of TV for half an hour or an hour on weekdays are respondents who can afford having evening prime time after work. They usually watch federal or regional news. The utmost number of weekend watchers are (3 or 4 hours) the representatives of high school students and elderly people. So, there were no testees who found it hard to say anything about NB.

Despite the common knowledge that men and women are alike in TV watching, the data show that women do it at any time of the day except late hours, men watch TV predominantly at nights.

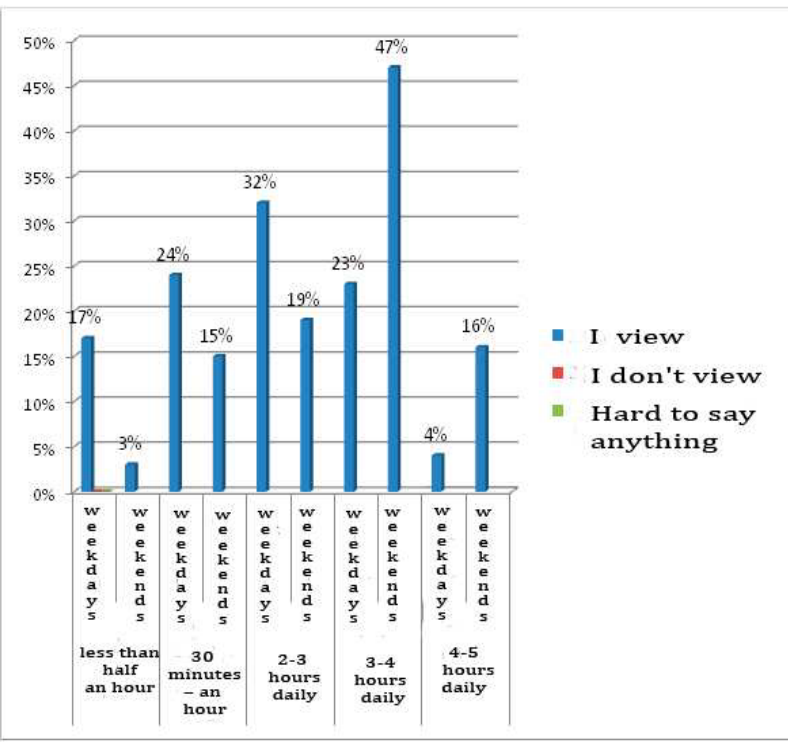

Fig 1. Watching time range: weekdays and weekends

As for federal and NB watching correlation, the subjects prefer to watch local programs daily: $46 \%-$ within 2-3 hours, $27 \%$ - 30 minutes to an hour, $13 \%-$ less than half an hour, $11 \%-3-4$ times a week, $3 \%-$ once or twice a week. It is necessary to note that there is $0 \%$ of the testees who do not watch regional programs (see Fig.2).

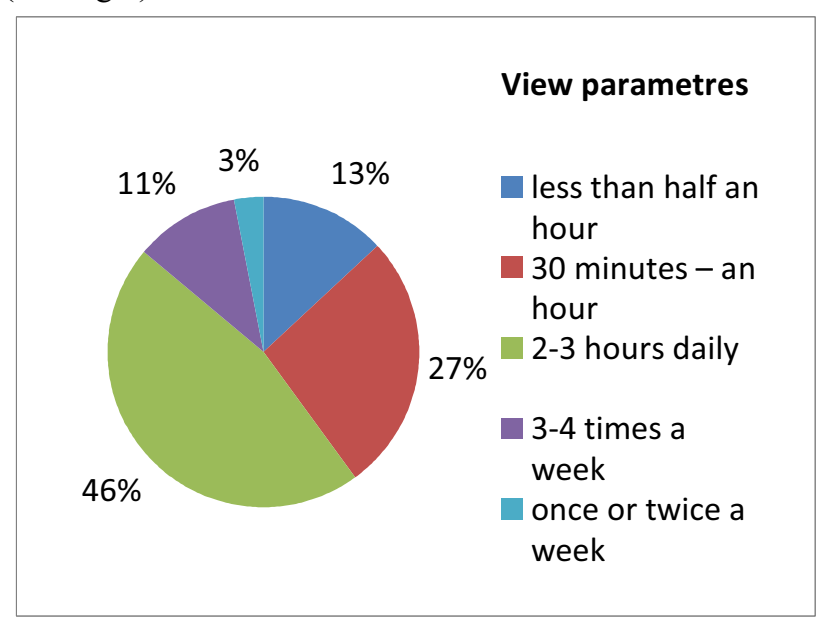

Fig 2. Regional channel watching

As to the issue of crucial importance - frequency of viewing TV programs in Buryat - it has the following view (Fig.3):

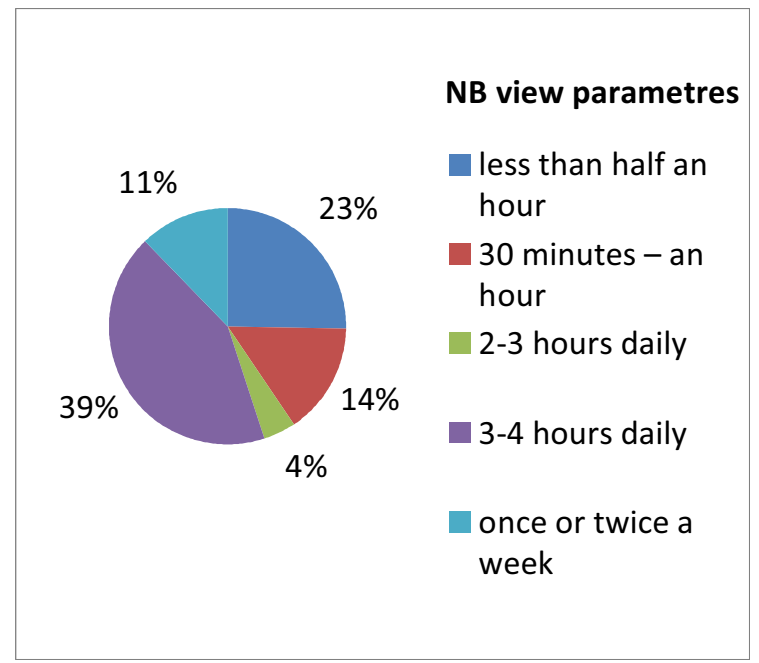

Fig 3. NB teleview

It turned out that people view NB programs more rarely (3-4 times a week), giving preference to federal broadcasting (2-3 hours a day). Among those who watch NB programs there are only $17 \%$ of viewers who do not view NB programs in the Buryat language. The latters are city-dwellers who do not know their mother tongue. The NB low rating is accounted for a small daily portion of broadcasting time and dispersion of programs worth viewing at an inconvenient time.

How and in what way the national TV broadcasting might help the Buryats strengthen their Buryat identity. The answer is quite predictable: via the revival of ethnic self-consciousness. Ethnic identity is primarily connected with ethnic self-consciousness revival and activation [4].

Ethnic self-consciousness in its broadest sense may be defined as "the feeling of belonging to this or that ethnicity expressed in ethnic self-identification, that is person's self-attachment to a definite ethnic group" [12].

In case ethnic identification becomes important to a person, we may conclude that his/her ethnic selfconsciousness is active. Moreover, even if one does not become a generator of ideas, she/he takes part in ethnic mobilization [3].

Thus, ethnic self-consciousness promotes people to find their place among other ethnic groups developing an overall outlook for the world. Being a part of different (social, intercultural) communications, ethnic selfconsciousness enables a person to achieve understanding of her/his and other ethnic communities.

The like understanding helps us clarify outcomes of a sociological inquiry of the rural population in two Buryat settlements. The both settlements are located considerably far from the center where there is no commercial TV. About 450 respondents took part in our inquiry. They all identify themselves as Buryats (100\%) who profess Buddhism (93,6\% of the respondents) and shamanism $(6,4 \%)$. The majority of them speak Buryat as a mother language, and $8,3 \%$ of them speak Russian as a mother tongue.

Within the sociological inquiry it was important to reveal the traits that are peculiar to the Buryats' ethnic identification - the data which would help us compare 
communication message images of the author and of the recipient and thus measure the communication effectiveness.

Table 2. An inquiry into responses to the question "Which factors would you name as the ones of the Buryats' integration?"

\begin{tabular}{|c|l|c|}
\hline & Parameters & $\mathbf{\%}$ \\
\hline 1 & genesis and history & 22 \\
\hline 2 & appearance & 10,3 \\
\hline 3 & $\begin{array}{l}\text { traditional material culture (national food, } \\
\text { clothes and etc.) }\end{array}$ & 7,8 \\
\hline 4 & $\begin{array}{l}\text { peculiarities of the national character and } \\
\text { behavior }\end{array}$ & 12,7 \\
\hline 5 & tribal relations & 7,7 \\
\hline 6 & religion & 12 \\
\hline 7 & language & 13,6 \\
\hline 8 & native land, nature, territory & 13,9 \\
\hline & Total: & 100 \\
\hline
\end{tabular}

According to the data in Table 2, the most significant factors in the process of integration and consolidation are Buryats' common genesis and history (22\%), homeland, nature, territory $(13,9)$, language $(13,6)$, peculiarities of the national character and behavior (12,7), religion (12), appearance $(10,3)$. All these factors are represented in national TV channels.

About 87,9 respondents consider that the TV NB conveys them a feeling of belonging to the ethnic group. The ways national TV channels transmit this feeling is shown below.

Table 3. An inquiry into responses to the question "How does NB convey the feeling of belonging to a certain folk?"

\begin{tabular}{|c|c|c|}
\hline & Parameters & $\%$ \\
\hline 1 & $\begin{array}{l}\ldots \text { when I hear native songs about my } \\
\text { homeland and people in my native language }\end{array}$ & 32 \\
\hline 2 & $\begin{array}{l}\ldots \text { when I hear about outstanding achievements } \\
\text { of the people of my ethnic background }\end{array}$ & 23,6 \\
\hline 3 & $\begin{array}{l}\text {... when I watch social-related programs, } \\
\text { especially showing injustice when people of my } \\
\text { ethnic background do not get a job worth their } \\
\text { abilities and business proficiency }\end{array}$ & 13 \\
\hline 4 & $\begin{array}{l}\ldots \text { when I watch ethnic holidays and } \\
\text { celebrations on TV }\end{array}$ & 28 \\
\hline 5 & $\begin{array}{l}\text {... when people discuss the history of native } \\
\text { folk on TV }\end{array}$ & 16,4 \\
\hline 6 & $\begin{array}{l}\text {... when they show datsans (buddhist temples) } \\
\text { and other sacred places }\end{array}$ & 17 \\
\hline 7 & Other & 0 \\
\hline
\end{tabular}

According to the results (table 3), 32\% of the respondents preferred watching the programs about homeland in the native language and it helps them to get closer to their folk. Also the feeling of being the ethnos part is conveyed via programs about national holidays (28\%), people's outstanding achievements (23,6\%), about datsans and other sacred places of Buryatia (17\%), history of the folk $(16,4 \%)$ and social injustice related to Buryat people (13\%).

Another question concerned the traits that people generate while watching TV.
Table 4. An inquiry into responses to the question "What kind of traits does the national program form?"

\begin{tabular}{|c|l|c|}
\hline & Parameters & $\%$ \\
\hline 1 & Love to native land & 53,4 \\
\hline 2 & Citizenship & 39,4 \\
\hline 3 & Humaneness & 84,5 \\
\hline 4 & Respect to elder people & 73,2 \\
\hline 5 & Respect to other nationalities & 69,2 \\
\hline 6 & Honesty & 38,5 \\
\hline 7 & Fair-mindedness & 16,2 \\
\hline 8 & Cynicism & 0,8 \\
\hline 9 & Cruelty & 0,2 \\
\hline 10 & Absence of commitment to principles & 0,1 \\
\hline 11 & Other & 0,7 \\
\hline 12 & Hard to find an answer & 1,6 \\
\hline
\end{tabular}

As we see, the NB content generally builds positive characteristics like humaneness $(84,5 \%)$, love to native land $(53,4 \%)$, the trait especially important for all the Buryats is respect for the elders $(72,2 \%)$, not less valued factor - respect to other nationalities $(69,2 \%)$ - ensures a tolerant society. Also we observe a high percentage of such qualities as citizenship (39,4\%), honesty (38,5\%) and fair-mindedness (16,2\%).

In the next direct question we asked the testees to name several national TV programs that help people to get to know more about the lives and creative work of their favorite Buryat artists, actors and actresses, painters and composers. In the table below we place most frequently mentioned people and the programs that reported about them.

Table 5. An inquiry into responses to the question "Can you name several national programs from which you learnt much about your favorite Buryat artists, actors and actresses, painters and composers?"

\begin{tabular}{|c|l|l|}
\hline & $\begin{array}{l}\text { Programs } \\
\text { mentioned by the } \\
\text { respondents }\end{array}$ & $\begin{array}{l}\text { Buryat artists, actors and actresses, } \\
\text { painters and composers }\end{array}$ \\
\hline 1 & "Buryad Oron" & $\begin{array}{l}\text { Valerii Inkizhinov, Olga } \\
\text { Zhigmitova, Solbon Lygdenov }\end{array}$ \\
\hline 2 & "Mungen Serge" & $\begin{array}{l}\text { Erdeni Zhaltsanov, Dashi } \\
\text { Namdakov, Zorigto Dorzhiyev, } \\
\text { Solbon Lygdenov }\end{array}$ \\
\hline 3 & "Gulamta" & $\begin{array}{l}\text { Yelena Sharayeva, Kim } \\
\text { Bazarsadayev, Bau Yampilov }\end{array}$ \\
\hline
\end{tabular}

The respondents' opinions correspond to the rating of both the national programs and most well-known hosts. The programs that heightened interest in the Buryat national rituals, customs and holidays are represented in Fig.4. Thus, we found out that 63,5 per cent of people watching national programs learnt more about the Buryat national holiday "Sagaalgan" or New Year by the lunar calendar. $23,8 \%$ of the respondents found out more about summer holidays "Surkharbaan". 7,3\% of the testees were better informed about the peculiarities of matrimonial traditions. $2.7 \%$ of the subjects pointed at Yokhor Naadan and Shagai Naadan, related to the programs, which broadcast traditional Buryat dancing and games. 


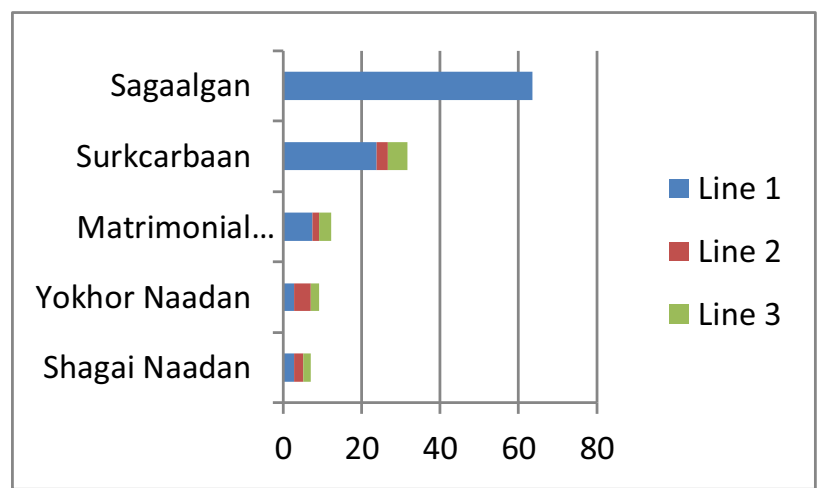

Fig. 4. Respondents' answers regarding obtaining knowledge from national programs about Buryat traditions and customs and mentioning frequency, $\%$

It is worth noting that $33,5 \%$ of the respondents keep their traditions and customs alive after watching topiccentered programs, $41,2 \%$ answered that they partially do it. There were $13,4 \%$ of those who do not keep them alive and $11,9 \%$ did not know what to say.

Table 6. An inquiry into responses to the question "Do the programs in the mother tongue help the Buryat people unify?"

\begin{tabular}{|c|l|c|}
\hline & Parameters & $\%$ \\
\hline 1 & $\begin{array}{l}\text { Yes, they do, because only by means of TV } \\
\text { broadcasting we can get unified }\end{array}$ & 31,9 \\
\hline 2 & $\begin{array}{l}\text { Yes, they do, as they transmit different } \\
\text { programs that unite Buryats }\end{array}$ & 52,3 \\
\hline 3 & $\begin{array}{l}\text { Yes, when I watch programs in the Buryat } \\
\text { language, I feel belonging to my ethnic group }\end{array}$ & 10,4 \\
\hline 4 & $\begin{array}{l}\text { No, they do not, because the national } \\
\text { programs low rating cannot disseminate } \\
\text { ethnic unification ideas }\end{array}$ & 3,8 \\
\hline 5 & Other & 1,6 \\
\hline 6 & I don't know & 0 \\
\hline & Total & 100 \\
\hline
\end{tabular}

There were the following responses to the question "Whether NB channel information is worth trusting? »: $87,5 \%$ of people feel that it is quite trustworthy, $10,3 \%$ think it is not quite trustworthy, $1,3 \%$ believe it is not at all trustworthy, $0,9 \%$ of the testees could not decide (see Fig.5). These data confirm that the degree of trust to NB programs in Buryat is high.

In the question on the NB impact on intraethnic identification there appears a related problem: whether NB affects lifelong objectives choice, motivations and social living guides. The response data are shown in table 7 .

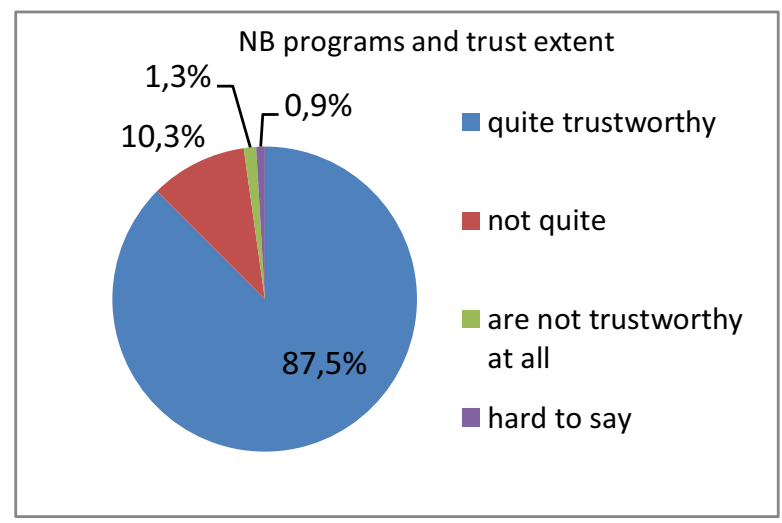

Fig.5. NB programs and the trust degree

Table 7. Does NB affect lifelong objectives choice, motivations and social living guides?

\begin{tabular}{|c|l|c|}
\hline 1 & $\begin{array}{l}\text { Parametres } \\
\text { realization }\end{array}$ & $\%$ \\
\hline 2 & $\begin{array}{l}\text { NB teaches to build a proper family, hearth } \\
\text { and home }\end{array}$ & 59,6 \\
\hline 3 & $\begin{array}{l}\text { NB shows samples of national heroes, it } \\
\text { guides me to live my life in the name of } \\
\text { my nation and for its sake }\end{array}$ & 38,4 \\
\hline 4 & $\begin{array}{l}\text { NB nurtures a drive for high material } \\
\text { benefits and social standing promotion }\end{array}$ & 19,2 \\
\hline 5 & Other guides & 11,7 \\
\hline 6 & Hard to say & 16,1 \\
\hline
\end{tabular}

The outcomes show that the main NB guide is likely to be a call to build a proper hearth and home $(59,6 \%)$. Then a self-actualization idea goes $(47,9 \%)$, followed by NB sampling of national heroes, who would live in the name of the nation and for its sake $(38,4 \%)$.

$83,2 \%$ of the young people under study responded to the question «whether NB forms identity and ethnic selfconsciousness» in the affirmative, $13,4 \%$ - in the negative (see Fig.6).

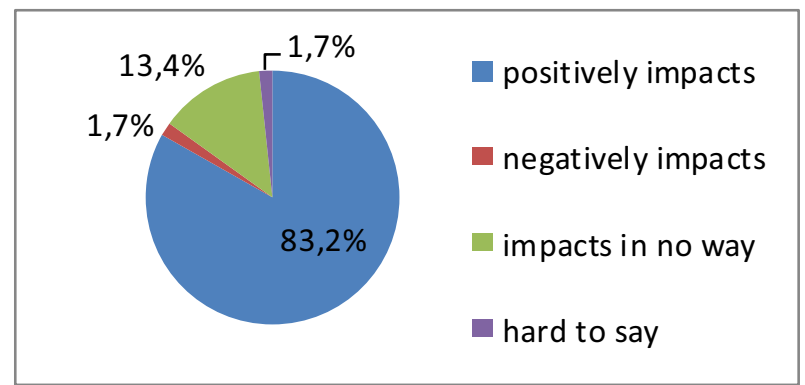

Fig. 6. NB impact on young people's identity and ethnic selfconsciousness

$76,9 \%$ of the testees said that NB improves their worldview scope, $17 \%$ denied that it does in any way or argued that it does to a limited extent. We assume that these $17 \%$ are the afore-mentioned respondents who have not acquired their mother language. 
So, it is obvious that the national TV broadcasting helps Buryat people unify for it transmits programs in the mother language $(52,3 \%)$, while watching the like programs people feel belonging to their folk (10, $4 \%$ ). And the absolute minority (3,8\%) of the respondents pointed at a low rating of national programs as the factor that hinders popularization of the unification ideas. On the whole, it is necessary to note that NB is undoubtedly an institute in need, a medium to promote ethnic selfconsciousness evolvement. Television has to be sustained among other modern record media and entertainment tools. The words "research and development activities are becoming more and more important for the development of the telecommunications industry. To a large extent they determine the competitive position of firms and nations", said at the end of the previous century, [8] remain still true at the beginning of the XXI century.

\section{Acknowledgment}

This article partially shows the outcomes of the research conducted by sociologists, philologists and the pedagogical experts of Buryat State University. It has been partially supported by a scientific research project (within the framework of state scientific order № $312 / 2015$, basic part). The title of the project is "Factor, institutional and temporal potential estimation of a postindustrial society in the aspect of knowledge economy formation and development at the regional level".

\section{References}

1. A. K. Aliyev, Kumyckski mir (2006)

2. G. Becker., N. Dagbaeva, Bildung für nachhaltige Entwicklung: Erfahrung der interkulturellen Zusammenarbeit (Verlag Nuso, 2012)

3. M. N. Guboglo, Etnosotsiologicheskiye ocherki (2003)

4. E. D Dagbaev, Vestnik of BSU, 6, (2010)

5. E. D. Dagbaev, Globalization and Mongolian world (2010)

6. P.P. Dashinimaeva, D.S. Sanditov, Buddhism in Culture Dialogue (2015)

7. L.D.Dryakhlova, Nationalnoe televidenie $v$ usloviyach regionalnoi polilingvistiki (na primere respubliki Mordoviya): disser.kand. philolog. nauk (2010)

8. H. Grupp, T. Schnöring, Telecommunications Policy, 16, (1992)

9. N. Kondakova, Press and ethnical tolerance posobiye (2000)

10. E. Kostina, L. Kretova, R. Teleshova, A. Tsepkova, T. Vezirov, Procedia - Social and Behavioral Sciences, 214, (2015)

11. V. K. Malkova: EO, 1, (2009)

12. Narody Rossii, Encyclopedia (1994)

13. D. L. Khilkhanov, History and Nowadays (2005)

14. O. Teppayayon, E. Bohlin, Telecommunications Policy, 34, (2010)
15. S.K. Zandeeva, Vestnik of BSU, 6 (1), (2012)

16. S.K. Zandeeva, Vestnik of BSU,.6 (1), (2014) 